\title{
Diversity and abundance of giant clams in Anambas Islands, Indonesia
}

\author{
Syawaludin Alisyahbana Harahap ${ }^{1, *}$, Yogi Yanuar², and Yuwanda Ilham² \\ ${ }^{1}$ Marine Department, Faculty of Fisheries and Marine Science, Padjadjaran University \\ ${ }^{2}$ Loka NACA Pekanbaru, MMAF Republic of Indonesia
}

\begin{abstract}
Absract. Giant clam is one of the most common types of bivalves found in coral ecosystem. Geographically, these clams have limited distribution in the Indo-Pacific tropics, from the Red Sea to the Pacific Islands of Tuamotu. Ecologically, the clam acts as bio-filtration and natural biodeposition. The presence of clams becomes a marker that the waters are still good and the absence of harmful pollutants. The population of this clam in Indonesian waters continues to decline. Anambas archipelago are known for its rich diversity of marine life. Since the establishment of this area became NACA as an ATP in 2014, marine tourism activities grew rapidly. Therefore it is necessary to do this research which aims to know the diversity of species and abundance of clams in the waters of Anambas Islands. Field survey was conducted in August 2015 by using Belt Transect method. The research results found 6 species with $D_{1}$ value is 0.593 . The overall abundance is 0.144 indv. $\mathrm{m}^{-2}$. Tridacna crocea has the highest abundance and relative abundance of the highest species of the other species of $60.54 \%$. Meanwhile, the smallest relative abundance is Tridacna gigas which is only $2.36 \%$.
\end{abstract}

\section{Keywords: Abundance, Anambas Islands, Diversity, Giant Clam}

\section{Introduction}

Tridacnidae or giant clam is one of the most common types of bivalves found in coral ecosystem waters. Giant clam lives in association with coral reefs by immersing themselves in the substrate (drill) or sticking to the sandy bottom of the water. These animals live in symbiosis with the dinoflagellata algae (Symbiodinium) that grow in the mantle tissue and are able to photosynthesize resulting in food and pigment [1].

Geographically, these clams have limited distribution in the Indo-Pacific tropics, from the Red Sea to the Pacific Islands of Tuamotu [2]. Around the world, this animal has two genera (Tridacna and Hippopus) consisting of nine species that are Tridacna gigas, Tridacna squamosa, Tridacna derasa, Tridacna maxima, Tridacna crocea, Tridacna tevoroa, Tridacna rosewateri, Hippopus hippopus and Hippopus porcellanus [3]. Seven species of giant clam apart from T. tevoroa and T. rosewateri are found in Indonesian waters [4].

Ecologically, the clams are the biota that acts as bio-filtration and natural biodeposition. This ability is because they are a deposit feeder or suspension feeder. They are also able to filter out ammonia and soluble nitrate in seawater for the need for zooxanthellae to nitrogen for its growth process [4]. The presence of clams becomes a marker that the waters are still good and the absence of harmful pollutants.

Giant clams (Tridacnidae) have been an important traditional source of food and income for many coastal Indonesian people. Kondisi ini menyebabkan tingkat populasinya di alam semakin sedikit. This is also the basis why the giant clam is one of the marine animals that

*Corresponding author: iwalhrp@gmail.com 
need to be protected throughout the world including in Indonesia. Since 1987, however, exploitation of natural stocks of giant clam has been prohibited by the Indonesian Government [5]. Government Regulation no. 7 of 1999 incorporated into seven types of clams living in Indonesia as protected animals. Nevertheless, the population of this clam in Indonesian waters continues to decline due to hunting, habitat destruction, use of fish bombs and potassium, as well as for the fulfillment of people consumption [6]. If this situation continues, it is feared that there will be a decline in population and lead to the extinction of various species of giant clam in nature. This situation has made this clam an animal that is included in appendix II list of CITES (Convention on International Trade in Endangered Species) [7].

Anambas archipelago is an archipelago located in the ecoregion of Sunda Shelf [8]. Geographically, this area is in the Natuna Sea (Fig. 1). This archipelago waters are known for its rich diversity of marine life. Since the establishment of this area became National Aquatic Conservation Area (NACA) as an Aquatic Tourism Park (ATP) in 2014, marine tourism activities grew rapidly.



Fig. 1. Orientation map of Anambas Islands position in Indonesi

In recent years and along with these conditions, the existence of marine ecosystems feared to be degraded. This was also coupled with the use of a variety of marine life including the exploitation of tridacna for different economic commodities. The study of species diversity and abundance, or at least species richness, gives ecologists insights into the stability of communities (Walker, 1988 in [9]).

Information on giant clams collected from various locations has been described by [10], but specifically for Anambas waters do not yet exist. Therefore it is necessary to do this research which aims to know the diversity of species and abundance of clams in the waters of Anambas Islands. The results of this study are expected to be used as information for the government and other stakeholders involved in the protection, conservation and utilization of giant clams and the management of their habitats in a sustainable manner. 


\section{Materials and Method}

\subsection{Survey}

Field survey was conducted in August 2015. A total of 23 sites were surveyed spread over in the waters of Anambas Islands (Fig. 2). The data collecting was conducted on 42 sampling points (Table 1).

Survey method used is a modification of Line Intercept Transect (LIT), namely Belt Transect and has been used previously by [11]. Each research station is only one transect line and pulled along the 70-meter transect line parallel to the coastline at a depth of 7-10 meters. Observations were made at every 1 meters to the right and the left of the transect line. Therefore, the area observed at each station is $140 \mathrm{~m}^{2}$ [12].

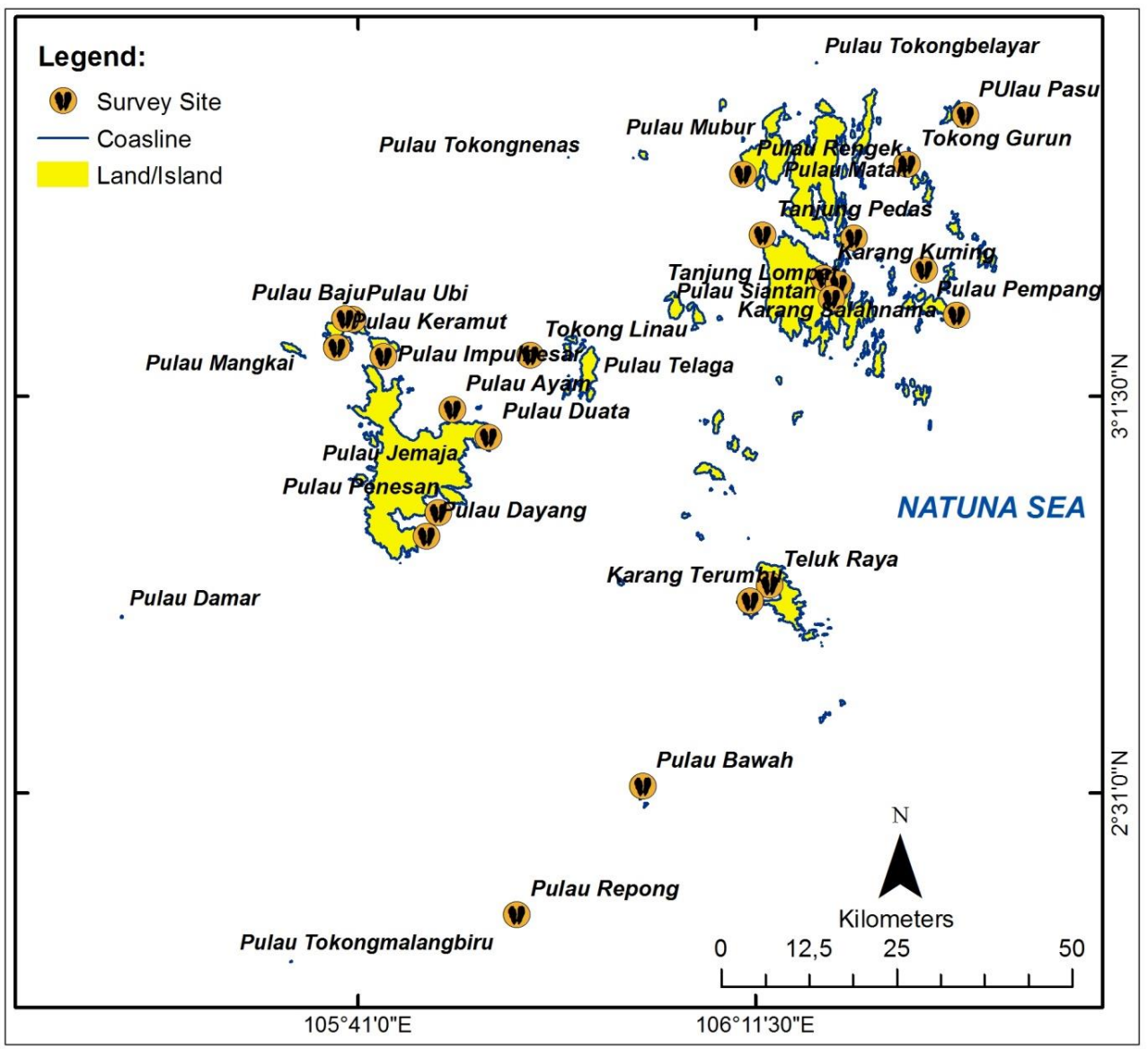

Fig. 2. Map of research location and survey sites

\subsection{Diversity Index}

Measuring and analyzing of diversity based on Simpson's Index (D). Simpson's Diversity Index is a measure of diversity. In ecology, it is often used to quantify the biodiversity of a habitat. It takes into account the number of species present, as well as the abundance of each species. Simpson's diversity index $\left(\mathbf{D}_{\mathbf{1}}\right)$ performed best when differentiating sites, but simpler indices were slightly preferable when detecting effects of land use intensity on diversity [13]. The formula to calculate species diversity according to Simpson is: 


$$
D_{1}=1-\sum P_{i}^{2}
$$

where $P_{i}$ is the proportion of individuals found in species i. For a well-sampled community, we can estimate this proportion as $\mathrm{P}_{\mathrm{i}}=\mathrm{n}_{\mathrm{i}} / \mathrm{N}$, where ni is the number of individuals in species $\mathrm{i}$ and $\mathrm{N}$ is the total number of individuals in the community. The range is from 0 to 1 , where:

- High scores (close to 1) indicate high diversity.

- Low scores (close to 0) indicate low diversity.

\subsection{Abundance}

There are 2 abundances analyzed, the first is the abundance and the second is the relative abundance. Calculation of giant clam abundance found in each station is calculated based on [14].

$$
A=\frac{N}{\text { area }}
$$

where $\mathrm{A}$ is abundance, $\mathrm{N}$ is total of Individu (indv.) and area is wide of sampling area (meter), meanwhile to calculate relative abundance using equation:

$$
R A=\frac{n_{i}}{N} \times 100 \%
$$

where RA is Relative abundance, ni is the number of individuals in species $\mathrm{i}$ and $\mathrm{N}$ is the total number of individuals in the community.

\section{Results and Discussion}

\subsection{Species Diversity of Giant Clams}

The results of research, from the 23 sites censused 849 individual of giant clams were found, comprising 6 species from 2 generas: Tridacna gigas $(\mathrm{n}=20)$, T. squamosa $(\mathrm{n}=79)$, T. derasa $(\mathrm{n}=77)$, T. maxima $(\mathrm{n}=125)$, T. crocea $(\mathrm{n}=514)$, and Hippopus hippopus $(\mathrm{n}=$ 34). However, none of the surveyed sites were found in the six species. Maximum only found 5 species. There are only 4 sites have highest of species number such as in Karang Beretih, Teluk Raya, Pulau Bawah and Pulau Impulbesar. Meanwhile, in the sites of Karang Kuning and Karang Terumbu found only 1 species of each Tridacna crocea and $T$. maxima. (Table 1).

The number of species of clams found in this region is more than half the number of species of clams in Indonesia and even in the world. The comparison can also be seen with the waters of the Seribu Islands and Manado [2] which each has only 3 and 4 species. Even for the relatively close waters of Reef's Singapore, only 2 species are found [15]. Greater diversity of giant clam found in the central Indo-Pacific [16].

In Table 1 it can also be seen that Simpson's diversity index $\left(D_{1}\right)$ at each site ranges from $0-0.727$. The highest $\mathrm{D}_{1}$ value are in the Karang Beretih site, whereas the lowest $\mathrm{D}_{1}$ value is in Karang Kuning and Karang Terumbu. Overall, the giant clam diversity index based on Simpson's diversity index $\left(\mathrm{D}_{1}\right)$ in Anambas Islands waters is 0.593 (Table 2). The index value shows a relatively high diversity because the value is more than 0.5 on a scale of 0 to 1 . 
Table 1. Giant Clams Numbers and Diversity in each site of Anambas Islands Waters

\begin{tabular}{|c|c|c|c|c|c|c|c|c|c|c|}
\hline \multirow{2}{*}{ Sites } & \multirow{2}{*}{$\begin{array}{l}\text { Num. Of } \\
\text { Transect }\end{array}$} & \multicolumn{7}{|c|}{ Number of Giant Clams ${ }^{\#}$ (Indv.) } & \multirow{2}{*}{$\begin{array}{l}\text { Num. Of } \\
\text { Species }\end{array}$} & \multirow{2}{*}{$\mathbf{D}_{1}$} \\
\hline & & n1 & n2 & n3 & n4 & n5 & n6 & Tot. & & \\
\hline Pulau Pasu & 2 & 48 & 0 & 0 & 0 & 9 & 0 & 57 & 2 & 0,266 \\
\hline Tokong Gurun & 2 & 39 & 2 & 1 & 0 & 6 & 0 & 48 & 4 & 0,322 \\
\hline Pulau Pengerat & 2 & 109 & 0 & 0 & 1 & 31 & 2 & 143 & 4 & 0,372 \\
\hline Karang Beretih & 2 & 21 & 1 & 13 & 7 & 0 & 14 & 56 & 5 & 0,727 \\
\hline Karang Kuning & 1 & 13 & 0 & 0 & 0 & 0 & 0 & 13 & 1 & 0,000 \\
\hline Karang Salahnama & 2 & 7 & 0 & 0 & 0 & 2 & 0 & 9 & 2 & 0,346 \\
\hline Tanjung Lompat & 2 & 5 & 1 & 0 & 0 & 2 & 1 & 9 & 4 & 0,617 \\
\hline Pulau Pempang & 2 & 28 & 0 & 0 & 0 & 12 & 0 & 40 & 2 & 0,420 \\
\hline Teluk Raya & 2 & 13 & 13 & 3 & 2 & 0 & 26 & 57 & 5 & 0,684 \\
\hline Karang Terumbu & 1 & 0 & 0 & 0 & 0 & 1 & 0 & 1 & 1 & 0,000 \\
\hline Pulau Bawah & 2 & 11 & 9 & 0 & 1 & 1 & 5 & 27 & 5 & 0,686 \\
\hline Pulau Repong & 3 & 1 & 0 & 6 & 0 & 4 & 3 & 14 & 4 & 0,684 \\
\hline Tokong Linau & 3 & 4 & 0 & 0 & 0 & 7 & 3 & 14 & 3 & 0,622 \\
\hline Pulau Impulbesar & 2 & 112 & 6 & 19 & 0 & 30 & 4 & 171 & 5 & 0,526 \\
\hline Pulau Ubi & 1 & 5 & 0 & 9 & 0 & 0 & 0 & 14 & 2 & 0,459 \\
\hline Pulau Baju & 2 & 7 & 0 & 10 & 3 & 0 & 6 & 26 & 4 & 0,713 \\
\hline Pulau Keramut & 2 & 37 & 0 & 1 & 0 & 12 & 2 & 52 & 4 & 0,439 \\
\hline Pulau Ayam & 1 & 7 & 0 & 0 & 0 & 5 & 0 & 12 & 2 & 0,486 \\
\hline Pulau Dayang & 2 & 6 & 0 & 15 & 0 & 0 & 8 & 29 & 3 & 0,614 \\
\hline Pulau Penesan & 2 & 4 & 1 & 0 & 0 & 2 & 0 & 7 & 3 & 0,571 \\
\hline Tanjung Pedas & 1 & 16 & 1 & 0 & 0 & 0 & 1 & 18 & 3 & 0,204 \\
\hline Pulau Duata & 2 & 7 & 0 & 0 & 6 & 1 & 3 & 17 & 4 & 0,671 \\
\hline Pulau Rengek & 1 & 14 & 0 & 0 & 0 & 0 & 1 & 15 & 2 & 0,124 \\
\hline TOTAL & 42 & 514 & 34 & 77 & 20 & 125 & 79 & 849 & & \\
\hline
\end{tabular}

Table 2. Simpson's diversity index $\left(\mathrm{D}_{1}\right)$ of giant clams in Anambas Islands Waters

\begin{tabular}{rlrccc}
\hline No. & \multicolumn{1}{c}{ Species } & Num. of Giant Clams $\left.\mathbf{( n}_{\mathbf{i}}\right)$ & $\mathbf{P}_{\mathbf{i}}$ & $\mathbf{P}_{\mathbf{i}}^{\mathbf{2}}$ & $\mathbf{D}_{\mathbf{1}}\left(\mathbf{1}-\boldsymbol{\Sigma} \mathbf{P}_{\mathbf{i}}^{\mathbf{2}}\right)$ \\
\hline 1 & T. crocea & 514 & 0,605 & 0,367 & \\
2 & T. maxima & 125 & 0,147 & 0,022 & \\
3 & T. squamosa & 79 & 0,093 & 0,009 & \\
4 & T. derasa & 77 & 0,091 & 0,008 & $\mathbf{0 , 5 9 3}$ \\
5 & H. hippopus & 34 & 0,040 & 0,002 & \\
6 & T. gigas & 20 & 0,024 & 0,001 & \\
\cline { 1 - 3 } & $\boldsymbol{\Sigma}$ & $\mathbf{N}=\mathbf{8 4 9}$ & & $\mathbf{0 , 4 0 7}$ & \\
\hline
\end{tabular}

\subsection{Abundance (A) and Relative Abundance (RA)}

Overall, giant clams abundance from $5880 \mathrm{~m}^{2}$ (42 transects) of total area surveyed in Anambas Islands is 0.144 indv. $\mathrm{m}^{-2}$ (Table 3). This condition still higher then other places in western Area In Indonesia like Karimunjawa Islands were ranged only from 0.03 to 0.04 indv. $\mathrm{m}^{-2}$ [17]. But still lower than the survey results in several other places in eastern area of Indonesia like in Cenderawasih Bay found giant clams natural populations densities were from 0.6 to 0.7 indv. $\mathrm{m}^{-2}[18]$.

In Table 3 and also the graph in Fig. 3 shows that $T$. crocea is the highest abundance of 0.087 indv. $\mathrm{m}^{-2}$. Tridacna. squamose and T. derasa have the same abundance of 0,013 indv. $\mathrm{m}^{-2}$. Meanwhile, the smallest abundance of 0.003 indv. $\mathrm{m}^{-2}$ is $T$. gigas. The data presented here indicate that giant clam abundance are low. This is very different from the results obtained in Ashmore, Mermaid and Cartier Reefs, located within the Great Barrier Reef, host populations in excess of 100 indv. $\mathrm{m}^{-2}$. Another example is on Tatakoto, French Polynesia, has an abundance of 90.9 indv. $\mathrm{m}^{-2}[19,20]$. 
Table 3. The number of giant clams, abundance and relative abundance of each species

\begin{tabular}{rlrrr}
\hline No. & Species & $\begin{array}{c}\text { Num. of } \\
\text { Giant Clams }\end{array}$ & $\begin{array}{c}\text { Abundance (A) } \\
\text { (indv.m }^{-2} \text { ) }\end{array}$ & $\begin{array}{c}\text { Relatif Abundance } \\
\text { (RA) (\%) }\end{array}$ \\
\hline 1 & T. crocea & 514 & 0,087 & 60,542 \\
2 & T. maxima & 125 & 0,021 & 14,723 \\
3 & T. squamosa & 79 & 0,013 & 9,305 \\
4 & T. derasa & 77 & 0,013 & 9,069 \\
5 & H. hippopus & 34 & 0,006 & 4,005 \\
6 & T. gigas & 20 & 0,003 & 2,356 \\
\hline \multicolumn{2}{c}{} & $\mathbf{8 4 9}$ & $\mathbf{0 , 1 4 4}$ & $\mathbf{1 0 0}$ \\
\hline
\end{tabular}

The results of the data analysis show that the RA of giant clam ranged between $2.36 \%$ to $60.54 \%$. Species of $T$. crocea has the highest abundance and relative abundance of the highest species compared with the other species that is equal to $60.54 \%$. Meanwhile, the smallest relative abundance is $T$. gigas which is only $2.36 \%$ (Fig. 4). Tridacna crocea, $T$. maxima, $T$ squamosa and $T$. derasa belong to predominant species, whereas $H$. hippopus and $T$. gigas belong to subdominant species. This grouping is based on the approach presented by [21] which states that if RA $>5 \%$ belongs to predominant species, RA 2-5\% belongs to subdominant species and $\mathrm{RA}<2 \%$ belongs to non-dominant species.

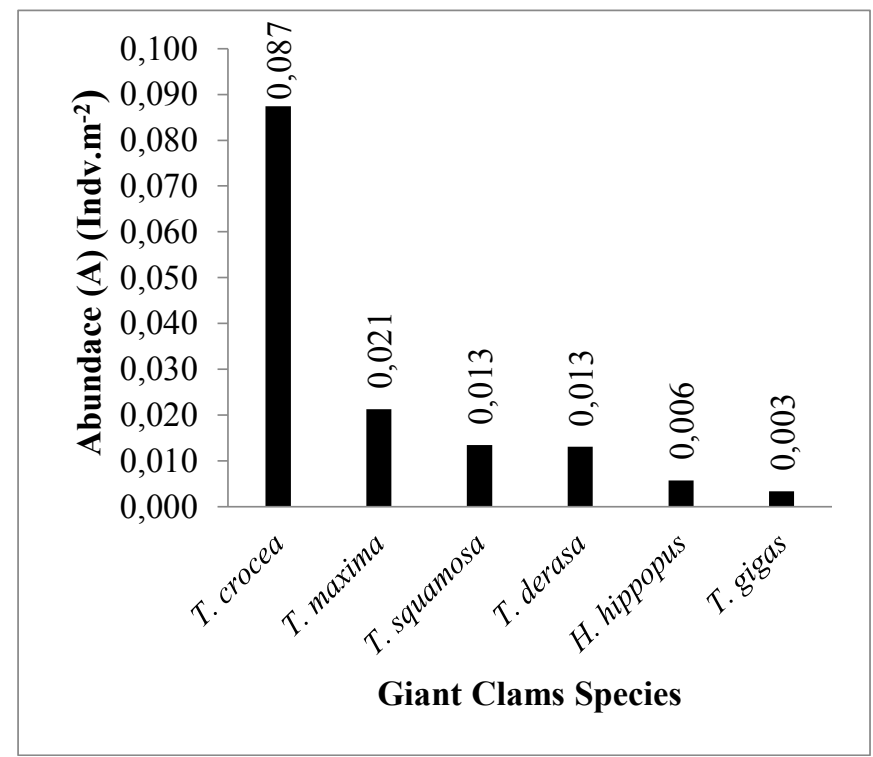

Fig. 3. Abundance of giant clam species

The composition of this abundance is similar to the observation of the population of giant clam in several places in Indonesian waters. The population is dominated by small species such as $T$. crocea and T. squamosa, while large species such as $T$. derasa and $T$. gigas are rarely found $[22,23]$. The high abundance of giant clam species in a waters is thought to be due to habitat factors suitable for the ability of the species to adapt and survive. The substrate type is one of the key factors in this regard [23]. 


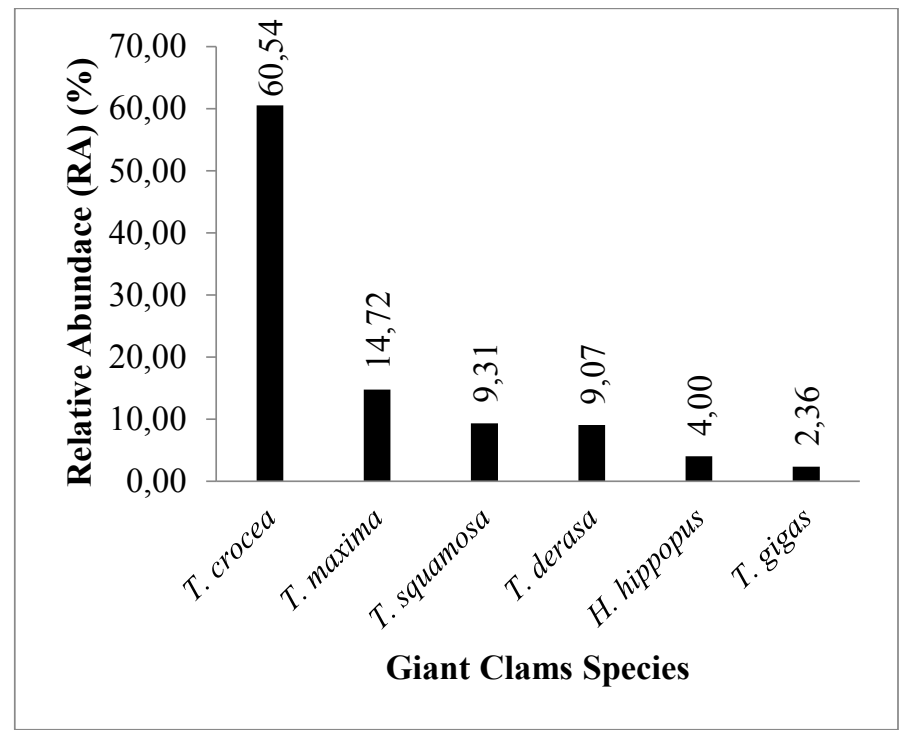

Fig. 4. Relative abundance of giant clams

All the species of giant clam identified in the Anambas Islands Waters to date vary greatly in their distribution and abundance, but all are threatened by overexploitation and habitat degradation. Even though they are listed by IUCN (International Union for Conservation of Nature) and international trade is CITES regulated, giant clam populations continue to decline [10].

\section{Conclusions}

The diversity of giant clam species found in Anambas Island waters shows 6 species from 2 generas namely Tridacna gigas, T. squamosa, T. derasa, T. maxima, T. crocea and Hippopus hippopus. The value of Simpson's diversity index $\left(\mathrm{D}_{1}\right)$ in each sites ranges from 0 - 0.727. The highest biodiversity index value located in Karang Beretih site. Overall in Anambas waters, the diversity index value of 0,593 indicates that the area has a relatively high diversity of giant clam.

Overall, giant clam abundance in Anambas Islands is 0.144 indv. $\mathrm{m}^{-2}$. The abundance dominated by $T$. crocea. The relative abundance $T$. crocea is the highest compared with the other species that is equal to $60.54 \%$. Meanwhile, the smallest relative abundance is $T$. gigas which is only $2.36 \%$

\section{Acknowledgements}

Thanks are given to Loka NACA Pekanbaru which has provided material support and personnel to the researchers to carry out surveys and give permission to publish the results of data survey.

\section{References}

1. Niartiningsih A. Giant Clam, Rere Marine Life: Cultivation and Conservation Makassar: Identitas Universitas Hasanuddin (2012)

2. Yusuf C, Ambariyanto , Hartati R. Abundance of Tridacna (Family Tridacnidae) at Seribu Island And Manado Waters, Indonesia. Ilmu Kelautan 14, 3: p. 150-154 (2009)

3. Lucas JS, Copland JW. Giant Clams in Asia and The Pacific. 1st ed. Canberra: 
Australian Centre of International Agricultural Research (1988)

4. Mudjiono. Note Aspect of Life Giant Clam Tridacnidae Family (Mollusca, Pelecipoda). Oseana 13, 2: p. 37-47 (1988)

5. Firdausy C, Tisdell C. Status of, and Demand for Giant Clams in Indonesia: a Survey of Four Coastal Villages in Bali and Java. In Tisdell C. Giant Clams in the Sustainable Development of the South Pacific. Canberra: Australian Centre for International Agricultural Research p. 101-116 (1992)

6. Setiawan H. Threats to Giant Clam Population (Tridacnidacna $s p$.) and conservation efforts in Taka Bonerate National Park. Info Teknis EBONE p. 137-147 (2013)

7. CITES. Appendices I, II and III. [Online] Available from: https://www.cites.org/eng/app/appendices.php (2017)

8. MMAF , MPAG. Geographic Priority Sea Biodiversity For The Development of Conservatioan Area In Indonesia. 1st ed. Huffard CL, Erdmann MV, Gunawan T, editors. Jakarta: Ministry of Marine Affairs and Fisheries-MMAF and Marine Protected Areas Governance-MPAG (2012)

9. Hamilton AJ. Species diversity or biodiversity? Journal of Environtmental Management 75, 2005: p. 89-92 (2005)

10. Othman AS, Goh GHS, Todd PA. The distribution and status of giant clams (Family Tridacnidae) - A short review. The Raffles Bulletin of Zoology 58, 1: p. 103-111 (2010)

11. Braley RD. Distribution and Abundance of Tridacna gigas and T. derasa in Great Barrier Reef. Micronesia 20: p. 215-223 (1987)

12. Arbi UY, Cappenberg HAW, Sihaloho HF. Megabenthic Monitoring. In Suharsono, Sumadhiharga OK. Guidance of Coral Reefs Health Monitoring. Jakarta: COREMAP CTI LIPI p. 63 (2014)

13. Morris EK, Caruso T, Buscot F, Fischer M, Hancock C, Maier TS, et al. Choosing and using diversity indices: insights for ecological applications from the German Biodiversity Exploratories. Ecology and Evolution 4, 18: p. 3514-3524 (2014)

14. Snedecor GW, Cochran. Statistical Methods. 7th ed. Ames Iowa USA: The Iowa State University Press (1980)

15. Neo ML, Todd PA. Population Density and Genetic Structure of The Giant Clams Tridacna crocea and T. squamosa on Singapore's Reefs. Aquatic Biology 14: p. 265275 (2012)

16. Spalding MD, Fox HE, Allen GR, Davidson N, Ferdaña ZA, Finlayson M, et al. Marine ecoregions of the world: a bioregional of coastal and shelf areas. BioScience 57, 7: p. 573-583 (2007)

17. Hadi S. Distribution of Giant Clams (Tridacnidae) in Burung Island, Karimunjawa. Filed Work Practice Report. Semarang (2000)

18. Pranowo WS. Distribution of Giant Clams (Family Tridacnidae) in Teluk Cenderawasih Marine National Park, Irian Jaya. Undergraduate Thesis. Semarang (1998)

19. Rees M, Colquhoun J, Smith LD, Heyward AJ. Survey of trochus, holothuria, giant clams and the coral communities at Ashmore, Cartier Reef and Mermaid Reef, 
northwestern Australia. Report to Environment Australia. Queensland (2003)

20. Gilbert A, Remoissenet G, Yan L, Andrefout S. The giant clam Tridacna maxima communities of three French Polynesia islands: Comparison of their population sizes and structures at early stages of their exploitation. ICES Journal of Marine Science 63: p. 1573-1589 (2006)

21. Van Balen B. Birds Counts and Bird Observation in Neighbourhood of Bogor. The Netherlands: Wageningham University (1984)

22. Allo, Setiawan MK, Dewi H, Bisjoe IN, Nurhayati AR, Qiptiyah M. Study of Tridacna crocea and Siganus canaliculatus ethnoecology in Takabonerate National Park. Research Result Report. Makassar (2010)

23. Padilah M, Pratomo A, Zulfikar A. Distribution Pattern of Giant Clam in Teluk Dalam Waters Malangrapat Village Gunung Kijang Subdistrict, Bintan Regency, Kepulauan Riau. Undergraduate Thesis. Tanjung Pinang (2015) 